\title{
A Case of Ochrobactrum intermedium Bacteremia Secondary to Cholangitis With a Literature Review
}

\author{
Ihab Kassab $^{1}$, Nadine Sarsam ${ }^{2}$, Saif Affas ${ }^{3}$, Mohamad Ayas ${ }^{3}$, Ji H. Baang ${ }^{4}$ \\ 1. Internal Medicine, University of Michigan, Ann Arbor, USA 2. Accident and Emergency Services, Luton \& Dunstable \\ University Hospital, Luton, GBR 3. Internal Medicine, Ascension St. John Hospital, Detroit, USA 4. Internal \\ Medicine/Infectious Disease, University of Michigan, Ann Arbor, USA
}

Corresponding author: Ihab Kassab, kassab.ihab@gmail.com

\begin{abstract}
Ochrobactrum species are gram-negative, non-lactose fermenting, aerobic bacilli closely related to Brucella genus. Ochrobactrum intermedium (O. intermedium) is an emergent human pathogen that is difficult to differentiate from other Ochrobactrum species by conventional methods. It is known to infect immunocompromised hosts, has the propensity for abscess formation, and is known for its multidrug resistance. We describe the case of an 84-year-old woman with a background of primary sclerosing cholangitis who presented with fatigue, fever, and syncope. Blood cultures grew O. intermedium. Magnetic resonance cholangiopancreatography and endoscopic retrograde cholangiopancreatography were consistent with cholangitis. Cultures from the biliary duct confirmed the same microorganism. The patient was successfully treated with minocycline. Although rare, O. intermedium should be considered as a differential diagnosis in patients with biliary and gut pathology, particularly in immunocompromised patients.
\end{abstract}

Review began 04/16/2021 Review ended 04/21/2021 Published 04/23/2021

\section{๑) Copyright 2021}

Kassab et al. This is an open access article distributed under the terms of the Creative Commons Attribution License CC-BY 4.0., which permits unrestricted use, distribution, and reproduction in any medium, provided the original author and source are credited.
Categories: Internal Medicine, Gastroenterology, Infectious Disease

Keywords: ochrobactrum species, ochrobactrum intermedium, cholangitis, ascending cholangitis, primary sclerosing cholangitis, bacteremia

\section{Introduction}

Ochrobactrum species are gram-negative, non-lactose fermenting, aerobic bacilli closely related to the Brucella genus. The Ochrobactrum genus was first identified in 1988. It was previously categorized as the Centers for Disease Control and Prevention (CDC) group Vd 1-2 [1-4]. Ochrobactrum species can be found in the environment such as water, soil, animals, and plants, as well as in polluted environments $[1,5]$. It is also thought to be part of the normal flora of our large intestines [6]. The Ochrobactrum genus includes nine different species: O. anthropi, O. intermedium, O. lupini, O. tritici, O. grignonense, O. gallinifaecis, O. oryzae, O. pseudintermedium, and O. cytisi. Out of these, only O. anthropi, O. intermedium, and O. pseudintermedium have been reported to cause clinical manifestations [7].

Although Ochrobactrum species have been recognized as opportunistic human pathogens with low virulence, most of the cases reported are about $O$. anthropi, which is usually associated with intravenous catheter infections and is commonly seen in immunocompromised patients $[8,9]$. On the other hand, O. intermedium, which is an emergent human pathogen that is difficult to differentiate from other Ochrobactrum species by conventional methods, has been rarely reported in the literature. Ochrobactrum intermedium has the tendency to form microabscess and is notorious for its multidrug resistance [5].

We present a case of cholangitis secondary to O. intermedium infection in an 84-year-old patient who was successfully treated with minocycline.

\section{Case Presentation}

An 84-year-old woman with a history of primary sclerosing cholangitis (PSC) with compensated cirrhosis without ascites, esophageal varices, or encephalopathy presented to our hospital with fatigue, fever, and syncope. Review of systems was negative for abdominal pain, cough, shortness of breath, and urinary symptoms. She had no history of weight loss. She denied any use of tobacco, alcohol, or illicit drugs. She had a body mass index (BMI) of $22 \mathrm{~kg} / \mathrm{m}^{2}$. She was noted to have a fever of $39.5^{\circ} \mathrm{C}$ with a normal pulse and blood pressure. On examination, she was awake and oriented, with no focal neurological signs. She had normal breath and heart sounds on auscultation. Her abdomen was soft and nontender. Laboratory work showed a white blood cell count of $12.7 \mathrm{~K} / \mathrm{uL}(4-10 \mathrm{~K} / \mathrm{uL})$ and a hemoglobin of $14.7 \mathrm{~g} / \mathrm{dL}(12-16 \mathrm{~g} / \mathrm{dL})$. Her comprehensive metabolic panel was noted for elevated aspartate aminotransferase of $68 \mathrm{IU} / \mathrm{L}$ (8-30 IU/L), alanine aminotransferase of $84 \mathrm{IU} / \mathrm{L}$ (< $35 \mathrm{IU} / \mathrm{L})$, alkaline phosphatase of $200 \mathrm{IU} / \mathrm{L}$ (40-116 IU/L), and total bilirubin of $1.5 \mathrm{mg} / \mathrm{dL}(0.2-1.2 \mathrm{mg} / \mathrm{dL})$. The patient's baseline liver enzymes were normal. A chest X-ray was performed, which revealed right middle lobe atelectasis that appeared unchanged from prior chest X-rays. Blood cultures were obtained, and the patient was started on empirical intravenous antibiotics including 


\section{Cureus}

ampicillin/sulbactam $3 \mathrm{~g}$ and azithromycin $500 \mathrm{mg}$. Gram staining revealed gram-negative rods (Figure 1).

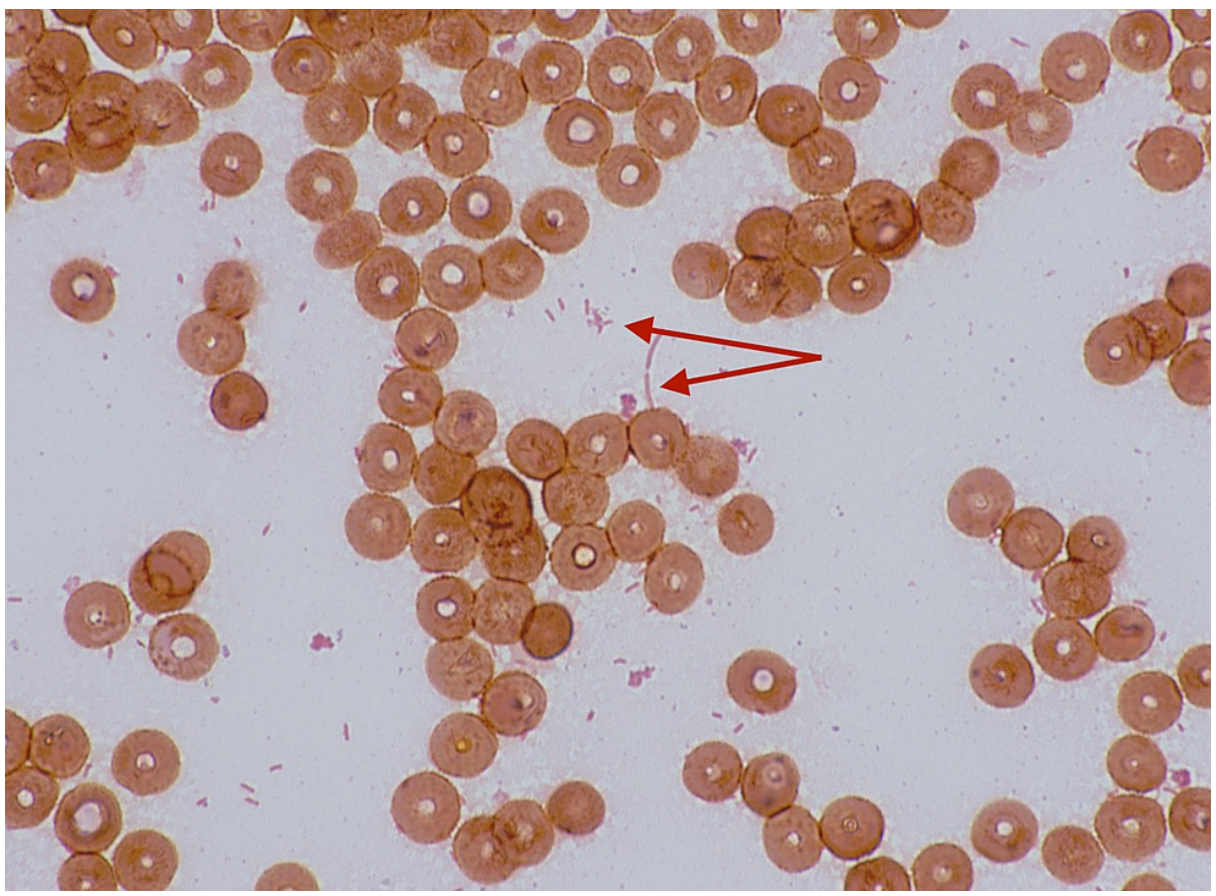

FIGURE 1: Gram staining showing gram-negative rods (red arrows)

Blood cultures grew $O$. intermedium within 48 hours of collection that was speciated with the matrix-assisted laser desorption/ionization-time of flight mass spectrometry (MALDI-TOF MS) method.

Antibiotics were broadened to meropenem while awaiting sensitivity. Despite that, the blood cultures remained positive for the same microorganism for three consecutive sets.

We performed a transthoracic echocardiography, which ruled out endocarditis. Additionally, magnetic resonance cholangiopancreatography (MRCP) was performed, which showed diffuse stricturing of the common bile duct throughout its course. There was severe multifocal stricturing of the central intrahepatic biliary tree with peripheral bile duct dilatation and irregularity compatible with sclerosing cholangitis. The MRCP imaging showed slight global worsening in the degree of biliary dilatation from prior scans. There was no evidence of hepatocellular carcinoma (Figure 2).

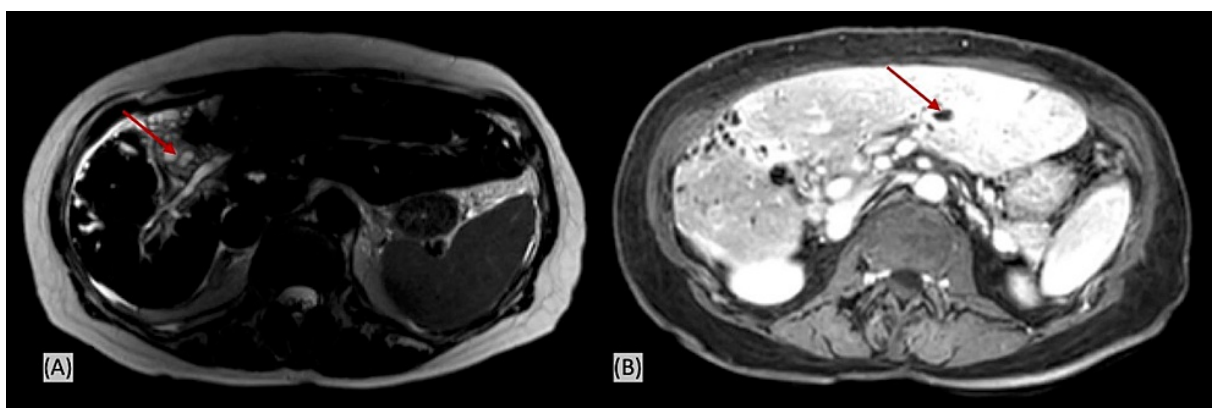

FIGURE 2: Magnetic resonance cholangiopancreatography (MRCP) showing diffuse common bile duct stricturing and biliary duct dilatation

Panel A: T2-weighed image; panel B: post-contrast T1-weighted image with fat saturation

This was followed by endoscopic retrograde cholangiopancreatography (ERCP), which showed a single severe biliary stricture in the extrahepatic bile duct resulting in intrahepatic ductal dilatation. A 6-mm biliary sphincterotomy was made. The biliary tree was swept revealing sludge and pus. The common bile duct was dilated with improved drainage after dilation. Cells for cytology were obtained by brushing into the entire extrahepatic bile duct (Figure 3). 


\section{Cureus}

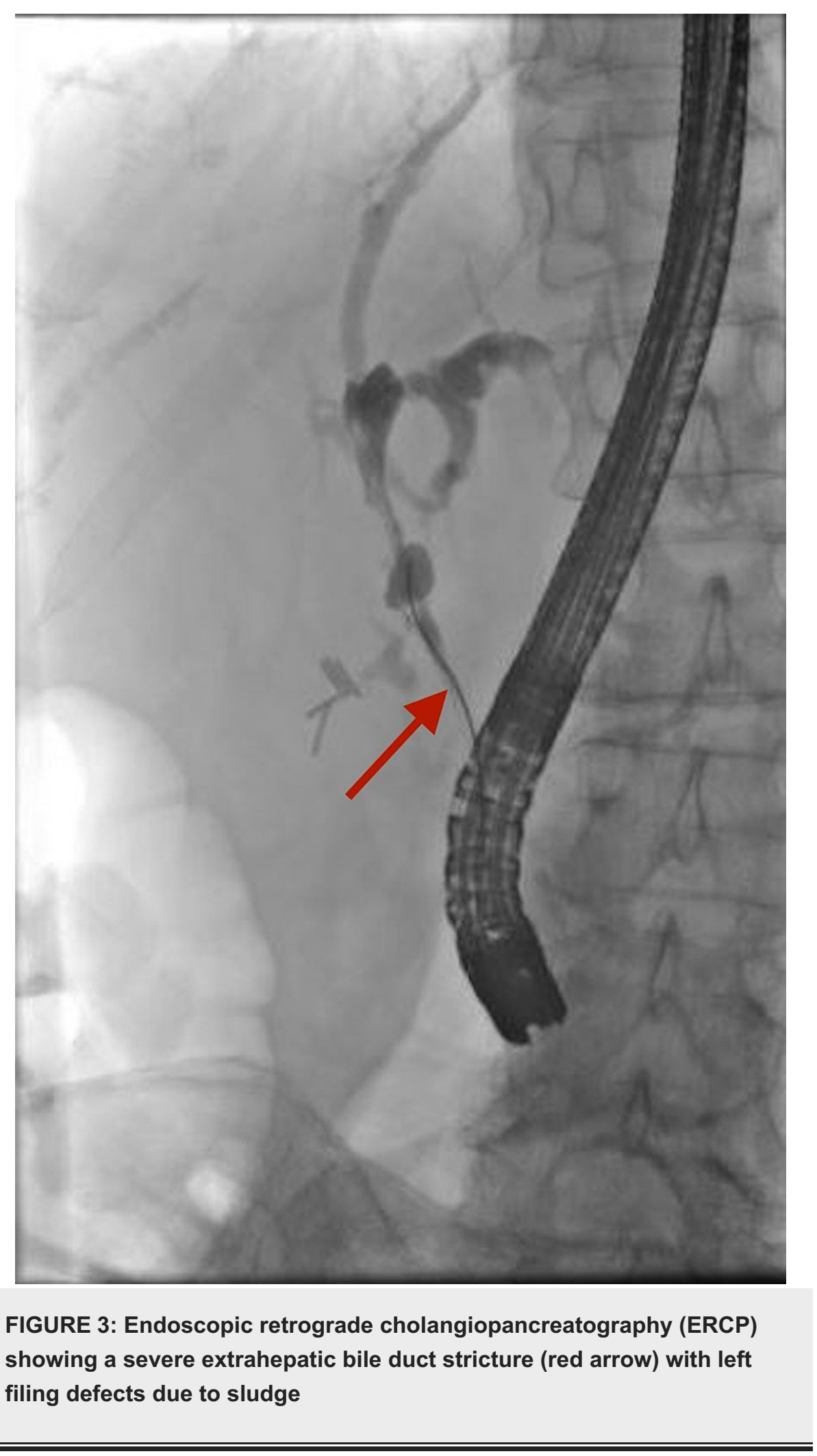

Common bile duct brush cytology showed no malignant cells. CA19-9 was negative. The patient was switched to minocycline as per sensitivity and was discharged home to finish a course of 14 days of minocycline.

\section{Discussion}

O. intermedium represents an emerging species that was first separated from O. anthropi in 1998 as it was not possible to differentiate them by standard tests until then. Additionally, $O$. intermedium has a closer relation to the Brucella genus than other species of Ochrobactrum as it shares $98.8 \%$ of its $16 \mathrm{~S}$ rRNA with this genus for which sophisticated molecular tests are required for differentiation, such as 16S rDNA gene sequencing, 
recA-PCR RFLP (Restriction Fragment Length Polymorphism), and MALDI-TOF MS method. The 16S rDNA gene sequencing is considered the gold standard technique in differentiating between those species. However, due to its high cost and lack of availability, MALDI-TOF is used alternatively, which has shown to be an effective and reliable tool in identifying microorganisms $[1,3,4,7,10]$. Our specimen was speciated with the MALDI-TOF MS.

Only a few cases of $O$. intermedium infections have been described in the literature. We conducted a retrospective PubMed literature search and found a total of 7 reported cases of $O$. intermedium (Table 1).

\begin{tabular}{|c|c|c|c|c|c|}
\hline Author (Year) & Age & Gender & $\begin{array}{l}\text { Immunity } \\
\text { Status }\end{array}$ & Presentation & Treatment \\
\hline $\begin{array}{l}\text { Möller et al., } \\
1999[6]\end{array}$ & 45 & Female & Compromised & $\begin{array}{l}\text { Patient presented with sepsis a month after receiving a liver } \\
\text { transplant due to primary sclerosis cholangitis and was found } \\
\text { to have cholangitis as well as multiple micro-abscesses in the } \\
\text { liver and one large abscess in the dome of the right lobe }\end{array}$ & $\begin{array}{l}\text { Imipenem, } \\
\text { tobramycin }\end{array}$ \\
\hline $\begin{array}{l}\text { Apisarnthanarak } \\
\text { et al., } 2005 \text { [9] }\end{array}$ & 74 & Male & Compromised & $\begin{array}{l}\text { Patient with a bladder cancer presented with a large bowel } \\
\text { obstruction, requiring a colostomy a month after radical } \\
\text { cystectomy }\end{array}$ & $\begin{array}{l}\text { Imipenem, } \\
\text { ciprofloxacin }\end{array}$ \\
\hline $\begin{array}{l}\text { Vaidya et al., } \\
2005[11]\end{array}$ & 49 & Male & Competent & $\begin{array}{l}\text { Patient presented with lower abdominal pain and appendicitis } \\
\text { complicated by perirectal abscess followed by bowel } \\
\text { obstruction and pelvic abscess }\end{array}$ & Fluoroquinolones \\
\hline $\begin{array}{l}\text { Dharne et al., } \\
2008 \text { [12] }\end{array}$ & NR & NR & NR & $\begin{array}{l}\text { Incidental finding in an asymptomatic patient on stomach } \\
\text { biopsy }\end{array}$ & NR \\
\hline $\begin{array}{l}\text { Jacobs et al., } \\
2013[13]\end{array}$ & 34 & Male & Competent & $\begin{array}{l}\text { Patient presented with endophthalmitis secondary to a metallic } \\
\text { intraocular foreign body }\end{array}$ & $\begin{array}{l}\text { Intravitreal, } \\
\text { moxifloxacin }\end{array}$ \\
\hline $\begin{array}{l}\text { Bharucha et al., } \\
2017 \text { [14] }\end{array}$ & 23 & Male & Compromised & $\begin{array}{l}\text { Patient on hemodialysis via right internal jugular catheter after } \\
\text { failing of renal transplant but still on immunosuppressor } \\
\text { presented with endocarditis }\end{array}$ & Meropenem \\
\hline $\begin{array}{l}\text { Hirai et al., } 2016 \\
\text { [10] }\end{array}$ & 86 & Male & Competent & $\begin{array}{l}\text { Patient who had a stroke and pontine infarction developed a } \\
\text { peripheral venous catheter infection }\end{array}$ & Meropenem \\
\hline
\end{tabular}

\section{TABLE 1: Retrospective PubMed literature search for reported Ochrobactrum intermedium cases}

In the reported cases, the median age of infection with $O$. intermedium was 47 years (range: $23-86$ years) $[10,14]$. Five cases were males [9-11,13,14], one case was a female [6], and in one case the gender was not reported. Ochrobactrum intermedium infection was largely associated with bacteremia and systemic manifestations $[6,9-11,14]$. Out of the seven reported cases, six patients had bacteremia, three of whom were immunocompromised $[6,9,14]$. Five of the reported cases were associated with systemic manifestations, as seen in our patient. Two cases were not associated with any systemic disease, one of which was a case of endophthalmitis secondary to metallic intraocular foreign body injury [13], and the other was an incidental finding of the microorganism on a stomach biopsy performed during esophagogastroduodenoscopy (EGD) for a patient with non-ulcerative dyspepsia [12]. Two cases were associated with intestinal obstruction as a complication $[9,11]$. Abscess formation was described in three cases $[6,9,11]$.

One case had a history of PSC associated with advanced liver cirrhosis, who presented with signs of septicemia one month after orthotopic liver transplantation and was diagnosed with cholangitis secondary to $O$. intermedium. The patient later developed ischemic-type biliary lesions that required re-transplantation six weeks post primary transplantation [6]. Our case is the second reported case of cholangitis secondary to O. intermedium. Similar to the aforementioned case, our patient had a history of PSC and developed cholangitis secondary to O. intermedium. However, our patient had early stages of cirrhosis (Child-Pugh A5) without complications and had no history of organ transplant. Although her liver cirrhosis was mild, it may have subjected her to a form of depressed immunity as studies have shown that the liver is a primary surveillance organ for intravascular infection and plays an important role in filtering various fungal and bacterial pathogens, and, therefore, patients with liver dysfunction are at increased risk of infection from a variety of pathogens [15]. 


\section{Cureus}

with imipenem [9]. Meropenem alone was used in two cases [10,11], while imipenem and tobramycin were used in one case [6].

Ochrobactrum intermedium microorganism is capable of producing pyogenic infections and has the characteristic of multidrug resistance. It is resistant to multiple families of antibiotics such as ß-lactum including penicillins, cephalosporins, and sometimes carbapenems. This makes treatment of Ochrobactrum bacteria often challenging, with most strains susceptible to fluoroquinolones, aminoglycosides, carbapenems, and trimethoprim-sulfamethoxazole (TMP-SMX) [4,6,16-19].

Our patient was sensitive to TMP-SMX, fluoroquinolones (ciprofloxacin and levofloxacin), tetracyclines (doxycycline and minocycline), carbapenems (imipenem and meropenem), and amikacin, and resistant to piperacillin/tazobactam, tobramycin, gentamicin, aztreonam, and ceftazidime (Table 2).

\begin{tabular}{|c|c|c|}
\hline Antibiotics & Susceptibility Profile & MIC \\
\hline Amikacin & Sensitive & $16 \mathrm{mcg} / \mathrm{mL}$ \\
\hline Aztreonam & Resistant & $>16 \mathrm{mcg} / \mathrm{mL}$ \\
\hline Cefepime & Intermediate & $16 \mathrm{mcg} / \mathrm{mL}$ \\
\hline Ceftazidime & Resistant & $>16 \mathrm{mcg} / \mathrm{mL}$ \\
\hline Ciprofloxacin & Sensitive & $0.25 \mathrm{mcg} / \mathrm{mL}$ \\
\hline Doxycycline & Sensitive & $\leq 2 \mathrm{mcg} / \mathrm{mL}$ \\
\hline Gentamicin & Resistant & $>8 \mathrm{mcg} / \mathrm{mL}$ \\
\hline Imipenem & Sensitive & $\leq 1 \mathrm{mcg} / \mathrm{mL}$ \\
\hline Levofloxacin & Sensitive & $\leq 0.5 \mathrm{mcg} / \mathrm{mL}$ \\
\hline Meropenem & Sensitive & $\leq 1 \mathrm{mcg} / \mathrm{mL}$ \\
\hline Minocycline & Sensitive & $\leq 2 \mathrm{mcg} / \mathrm{mL}$ \\
\hline Piperacillin/tazobactam & Resistant & $>64 \mathrm{mcg} / \mathrm{mL}$ \\
\hline Tobramycin & Resistant & $>8 \mathrm{mcg} / \mathrm{mL}$ \\
\hline Trimethoprim/sulfamethoxazole & Sensitive & $\leq 2 \mathrm{mcg} / \mathrm{mL}$ \\
\hline
\end{tabular}

\section{TABLE 2: Antibiotics susceptibility table for Ochrobactrum intermedium}

MIC, minimum inhibitory concentration

\section{Conclusions}

We described a rare case of $O$. intermedium ascending cholangitis complicated by bacteremia. Although rare, this organism should be considered as a pathogen in patients with biliary and gut pathology. The similarity of this bacterium with other Ochrobactrum species and with the Brucella genus makes the diagnosis challenging, requiring sophisticated methods for differentiation. We reported this case to heighten physicians' awareness on this type of bacteria, including early detection, identification of the source of infection, and the use of appropriate antibiotics for treatment. Ochrobactrum intermedium should be considered as a differential diagnosis particularly in immunocompromised patients presenting with cholangitis, abscess formation, endocarditis, and catheter-associated infections.

\section{Additional Information \\ Disclosures}

Human subjects: Consent was obtained or waived by all participants in this study. Conflicts of interest: In compliance with the ICMJE uniform disclosure form, all authors declare the following: Payment/services info: All authors have declared that no financial support was received from any organization for the submitted work. Financial relationships: All authors have declared that they have no financial relationships at present or within the previous three years with any organizations that might have an interest in the submitted work. Other relationships: All authors have declared that there are no other relationships or activities that could appear to have influenced the submitted work. 


\section{References}

1. Jäckel C, Hertwig S, Scholz HC, Nöckler K, Reetz J, Hammerl JA: Prevalence, Host range, and comparative genomic analysis of temperate Ochrobactrum phages. Front Microbiol. 2017, 8:1207.

10.3389/fmicb.2017.01207

2. Alnor D, Frimodt-Møller N, Espersen F, Frederiksen W: Infections with the unusual human pathogens Agrobacterium species and Ochrobactrum anthropi. Clin Infect Dis. 1994, 18:914-20. 10.1093/clinids/18.6.914

3. Rodríguez-Villodres Á, Cuevas Palomino Á, Gómez Gómez MJ: [Usefulness of MALDI-TOF mass spectrometry in infections by infrequent microorganisms such as Ochrobactrum intermedium]. Med Clin (Barc). 2016, 147:277-8. 10.1016/j.medcli.2016.04.019

4. Ryan MP, Pembroke JT: The genus Ochrobactrum as major opportunistic pathogens . Microorganisms. 2020, 8:1797. 10.3390/microorganisms8111797

5. Aujoulat F, Romano-Bertrand S, Masnou A, Marchandin H, Jumas-Bilak E: Niches, population structure and genome reduction in Ochrobactrum intermedium: clues to technology-driven emergence of pathogens. PLoS One. 2014, 9:e83376. 10.1371/journal.pone.0083376

6. Möller LV, Arends JP, Harmsen HJ, Talens A, Terpstra P, Slooff MJ: Ochrobactrum intermedium infection after liver transplantation. J Clin Microbiol. 1999, 37:241-4. 10.1128/JCM.37.1.241-244.1999

7. Kämpfer P, Citron DM, Goldstein EJC, Scholz HC: Difficulty in the identification and differentiation of clinically relevant Ochrobactrum species. J Med Microbiol. 2007, 56:1571-3. 10.1099/jmm.0.47350-0

8. Cieslak TJ, Robb ML, Drabick CJ, Fischer GW: Catheter-associated sepsis caused by Ochrobactrum anthropi: report of a case and review of related nonfermentative bacteria. Clin Infect Dis. 1992, 14:902-7. 10.1093/clinids/14.4.902

9. Apisarnthanarak A, Kiratisin P, Mundy LM: Evaluation of Ochrobactrum intermedium bacteremia in a patient with bladder cancer. Diagn Microbiol Infect Dis. 2005, 53:153-5. 10.1016/j.diagmicrobio.2005.05.014

10. Hirai J, Yamagishi Y, Sakanashi D, Koizumi Y, Suematsu H, Mikamo H: [a case of bacteremia caused by Ochrobacterium intermedium]. Kansenshogaku Zasshi. 2016, 90:129-33. 10.11150/kansenshogakuzasshi.90.129

11. Vaidya SA, Citron DM, Fine MB, Murakami G, Goldstein EJ: Pelvic abscess due to Ochrobactrum intermedium [corrected] in an immunocompetent host: case report and review of the literature. J Clin Microbiol. 2006, 44:1184-6. 10.1128/JCM.44.3.1184-1186.2006

12. Dharne MS, Misra SP, Misra V, Dwivedi M, Patole MS, Shouche YS: Isolation of urease-positive Ochrobactrum intermedium in the stomach of a non-ulcer dyspeptic patient from north India. J Microbiol Immunol Infect. 2008, 41:183-6.

13. Jacobs DJ, Grube TJ, Flynn HW Jr, et al.: Intravitreal moxifloxacin in the management of Ochrobactrum intermedium endophthalmitis due to metallic intraocular foreign body. Clin Ophthalmol. 2013, 7:1727-30. 10.2147/OPTH.S44212

14. Bharucha T, Sharma D, Sharma H, Kandil H, Collier S: Ochromobactrum intermedium: an emerging opportunistic pathogen-case of recurrent bacteraemia associated with infective endocarditis in a haemodialysis patient. New Microbes New Infect. 2017, 15:14-5. 10.1016/j.nmni.2016.09.016

15. Jenne CN, Kubes P: Immune surveillance by the liver . Nat Immunol. 2013, 14:996-1006. 10.1038/ni.2691

16. Holmes B, Popoff M, Kiredjian M, Kersters K: Ochrobactrum anthropi gen. nov., sp. nov. from human clinical specimens and previously known as group Vd. Int J Syst Evol Microbiol. 1988, 1:406-16. 10.1099/0020771338-4-406

17. Appelbaum PC, Campbell DB: Pancreatic abscess associated with Achromobacter group Vd biovar 1 . J Clin Microbiol. 1980, 12:282-3. 10.1128/JCM.12.2.282-283.1980

18. Cieslak TJ, Drabick CJ, Robb ML: Pyogenic infections due to Ochrobactrum anthropi. Clin Infect Dis. 1996, 22:845-7. 10.1093/clinids/22.5.845

19. Kern WV, Oethinger M, Kaufhold A, Rozdzinski E, Marre R: Ochrobactrum anthropi bacteremia: report of four cases and short review. Infection. 1993, 21:306-10. 10.1007/BF01712451 